Journal of

Food and Nutrition

\title{
Effect of sago consumption on NCDs clinical sign among who consuming sago in Kepulauan Meranti District, Riau Province, Indonesia
}

\section{Syartiwidya ${ }^{1,2}$, Drajat Martianto ${ }^{2}$, Ikeu Taziha ${ }^{2}$, Ahmad Sulaeman $^{2, *}$, Rimbawan $^{2}$}

${ }^{1}$ Food Security Agency Riau Province, Pekanbaru, 28143

${ }^{2}$ Departement of Community Nutrition, Human Ecology Faculty Bogor Agricultural University, Bogor 16880

${ }^{\star}$ Corresponding author: Ahmad Syartiwidya, Departement of Community Nutrition, Human Ecology Faculty Bogor Agricultural University, Bogor 16880; E-mail: syartiwidya_igm2015@apps.ipb.ac.id

Received Date: March 20, 2019 Accepted Date: April 04, 2019 Published Date: April 08, 2019

Citation: Syartiwidya (2019) Effect of sago consumption on NCDs clinical sign among who consuming sago in Kepulauan Meranti District, Riau Province, Indonesia. J Food Nutr 5: 1-11.

\section{Abstract}

Objectives: The objective of this study was to identify the effect of sago consumption on NCDs clinical sign among consuming sago in Kepulauan Meranti District, Riau Province.

Design: A cross-sectional study with selected purposively

Setting: The study was carried out in Kepulauan Meranti District, Riau Province, Indonesia

Subjects: One hundred and eighty-one subjects consuming sago.

Outcome measures: A questionnaire; Socio-demographic, lifestyle, family history of DM, and direct measurement; anthropometry, random capillary blood glucose (RCBG), cholesterol, systolic and diastolic blood pressure (SBP\&DBP), and waist circumference (WC).

Results: The majority of subjects rarely and often consuming sago had RCBG categorized as RCBG $<140 \mathrm{~mm} / \mathrm{dL}$ (91.2\%) with $65.2 \%$ normal body mass index (BMI). Socio-demographic, lifestyle (smoking and physical activity), family history of DM and clinical signs (cholesterol, SBP, DBP, and WC)were not significantly different for subjects in the RCBG $<140 \mathrm{~mm} / \mathrm{dL}$ group between those rare and often consuming sago. However, in the RCBG 140-200 mm/dL group, education level, family income, family history of DM, DBP and cholesterol significantly differed. There was a significant correlation between sago consumption with cholesterol and WC.

Conclusions: Consuming sago may have the potential as an alternative food to prevent the NCDs.

Keywords: Non-communicable diseases, prevention, risk factor, sago

(C)2019 The Authors. Published by the JScholar under the terms of the Creative Commons Attribution License http://creativecommons.org/licenses/ by/3.0/, which permits unrestricted use, provided the original author and source are credited. 


\section{Introduction}

Non-communicable diseases, (NCDs), are the leading cause of mortality worldwide with 41 million deaths each year, equivalent to $71 \%$ of all deaths globally. Each year, 15 million people die from an NCD between the ages of 30 and 69 years; over $85 \%$ of these "premature" deaths occur in low- and middle-income countries. Cardiovascular diseases account for most NCD deaths, or 17.9 million people annually, followed by cancers ( 9.0 million), respiratory diseases (3.9million), and diabetes mellitus or DM (1.6 million). A combination of genetic, physiological, lifestyle and environmental factors can cause these diseases. Some risk factors include unhealthy diets, lack of physical activity, smoking and secondhand smoke, and excessive use of alcohol [37].

$\mathrm{DM}$ is one of NCDs Individuals experiencing RCBG 140-200 mm/dL (5-10\%) can be at risk of developing DM which is a heterogeneous metabolic disorder characterized by long-term impairment of insulin secretion and damage [36,23]. RCBG $140-200 \mathrm{~mm} / \mathrm{dL}$ is a condition in which the blood glucose level is higher than RCBG $<140 \mathrm{~mm} / \mathrm{dL}$ but lower than the threshold of diabetes mellitus $[31,36]$. The prevalence of DM in the world continues to increase, and Indonesia is at sixth [16]. According to the data of the Indonesian Basic Health Research [20], the prevalence of DM under 15 doubled (2.1\%).

The prevalence of DM in Riau Province was $1.0 \%$, while it was $0.6 \%$ in Kepulauan Meranti District [20]. Type 2 diabetes mellitus (T2DM)is the most common form observed in adults. Two major groups of factors influence it, being unchangeable factors such as gender, age, the genetic history of DM, and changeable factors as smoking, alcohol, physical activity, obesity, hypertension, cholesterol, and sedentary $[9,33,4,16]$.

Decreasing the sensitivity of target tissues to the metabolic effects of insulin, known as insulin resistance in tissues, is one of the causes of T2DM. Obesity is one of the many risk factors that cause T2DM which can be measured through WC and BMI. The prevention of T2DM can be carried out by controlling the risk factors $[20,4]$. Some studies showed that traditional food could be an alternative to preventing RCBG 140-200 mm/dL from becoming T2DM by reducing hyperglycemia, insulin resistance, and obesity [30].

Sago is a traditional source of carbohydrates, besides rice, widely available in Indonesia (5.2 million hectares or $\pm 50 \%$ of the sago area in the world). It is spread in several provinces including Riau Province with Kepulauan Meranti District as a sago producer [6]. Sago is still consumed by most people even though it is not considered as a staple food. It has several advantages over other sources of carbohydrates. Sago has a low glycemic index (GI) around 27. It also contains resistant starch, high starch and amylose, and antioxidant. These nutrients play a role in maintaining RCBG $<140 \mathrm{~mm} /$ $\mathrm{dL}$ blood glucose by increasing the number of beta cells producing insulin, reducing hypoglycemic and improving lipid metabolism $[11 ; 33,21,35]$. However, rice, as the main source of carbohydrate in Asia, has a relatively higher GI (6493) and several studies have shown that it could increase the risk of T2DM $[10,28]$. On the other hand, low GI food may be useful in ameliorating hyperglycemia and glucose-over load associated with diabetic conditions [17].

Studies have shown that consuming sago was good for health in that it reduced blood glucose, LDL cholesterol, and triglycerides level. Thus, it could reduce the risk of T2DM, and heart disease [36,11,2]. Although Kepulauan Meranti District is a sago-producing region, T2DM incidence is still observed in the area. Therefore, researchers were interested to identify the effect of sago consumption on NCDs clinical sign among the sago-based agricultural community in Kepulauan Meranti District, Riau Province.

\section{Materials \& Methods Study Setting and Subjects}

This study used a cross-sectional design and was carried out from June to September 2017 in Kepulauan Meranti District, Riau Province. The research protocol was approved by the Research Ethics Commission involving Human Subjects of Bogor Agricultural University: 031/IT3. KEPMSM-IPB/SK/2017.The study involved 181 subjects living in several villages, namely Sungai Tohor, Tanjung Sari, Nipah Sendanu, Batin Suir and Lalang Tanjung. The subjects were selected purposively. The inclusion criteria were 1) the age of the subject, 35-80 years, 2) not hospitalized, and 3) not suffering from serious illness or chronic drug consumption. The subjects were divided into 2 groups; 1 ) a group consuming sago $<140 \mathrm{~g} /$ day, and 2) a group consuming sago $\geq 140 \mathrm{~g} /$ day.

\section{Data Collection Procedure}

The interviewer used questionnaires to collect data on the characteristics of the subjects (age, sex, education level, occupation, and family income). Anthropometry measurement was used to describe the BMI which consisted of weight and height using the SECA brand weighed (capacity 
of $100 \mathrm{~kg}$, accuracy of $0.1 \mathrm{~kg}$ ) and microtome stature meter (the accuracy of $0.1 \mathrm{~cm}$ ). The BMI was calculated through the formula of weight $(\mathrm{kg})$ divided by height $(\mathrm{m})$ squared. The measurements of WC were conducted using a tape measure $(0.1 \mathrm{~cm}$ accuracy). The measurement of RCBG and cholesterol was done using Easy Touch Model: GCU Made In Taiwan with glucose strips and cholesterol. Sphygmomanometer was used to determine SBP and DBP.

The family history of DM was obtained from questionnaires. Physical activity was recorded based on physical activity forms or daily activities in minutes monitored in 24-hour activities. All values were expressed in metabolic multiples of BMR called metabolic rate (MR). The results of the calculation of the metabolic rate were categorized according to the assessment of physical activity levels. It was classified into high $(\mathrm{MR}>2.09)$, moderate $(\mathrm{MR}<1.76-2.09)$ and mild $(\mathrm{MR}<1.76)$. Smoking exposure was obtained from a questionnaire.

\section{Measurement of Dietary intake}

The amount of sago (consumed by the subjects) was determined by the SQ-FFQ questionnaire from 71 food items and analyzed using the Indonesia food table composition in 2013. The amount of sago was summed in 1 week based on meal frequency and divided by seven to get the daily consumption. This study surveyed the information about the meals, foods, and items consumed for $24 \mathrm{~h}$ before the survey and explained that it was a survey on the intake, which would reflect the subjects' dietary life level in ordinary times, recorded from food recall $24 \mathrm{~h}$. To assess the subjects' sago consumption, this study examined the levels of intake of several kinds of sago product like sago noddle, bihun sago, lempeng sago (sago plus grated coconut in the shape of a plate eaten with fried anchovy), sempolet (sago pulp with added shrimp, snails, squid or shellfish and fern vegetables), sago rendang (small granule sago eaten with bananas), gobak (such as sago plates but not shaped plates), sago mutiara (sago in the form of granules cooked with added sugar and coconut milk), kapurun (sago pulp eaten with fish curry), sesagon (sago in grains with coconut grated), and sago lemak (sago in the form of granules made with the addition of coconut milk).

\section{Statistical Analysis}

The analysis was conducted using SPSS 18.0 (IBS SPSS Statistics, Armonk, NY, USA). The data on food intake were processed using Nutrisurvey software. Data for the descriptive statistics of the variables were expressed as mean \pm standard deviation (SD). Bivariate analysis using an independent t-test to compare the two groups and a Pearson correlation to find out the relationship among the factors with RCBG 140-200 $\mathrm{mm} / \mathrm{dL}$. A p-value $<0.05$ and $\leq 0.01$ was considered significant. Grouping of subjects based on the research by Hariyanto et al.,[11] which states that sago consumption 140gr / day could reduce blood glucose, cholesterol and triglyceride levels in diabetic patients.

\section{Results}

\section{Characteristics of the Subjects}

The results showed that subjects consuming sago $\geq$ $140 \mathrm{~g} /$ day (55.25\%) were more than those consuming $<140 \mathrm{~g} /$ day (44.75\%). Subject consuming $\geq 140 \mathrm{~g} /$ day sago were mostly female with age $\geq 50$ years (56\%), and male (44\%). Most of the subjects had low education in both groups, i.e., $<140 \mathrm{~g} /$ day $(81.5 \%)$ or $\geq 140 \mathrm{~g} /$ day (91\%), respectively. Most of the subjects had low income in both groups, consuming sago $<140 \mathrm{~g} /$ day $(86.4 \%)$ and $\geq 140$ g/day (94\%).

As shown in Table 2,the means $\operatorname{BMI}(23.67 \pm 5.09)$ in both groups consuming sago $<140 \mathrm{~g} /$ day and $\geq 140 \mathrm{~g} /$ day were categorized as RCBG $<140 \mathrm{~mm} / \mathrm{dL}$ (65.2\%). These results were supported by data in Table 1 , i.e., the mean physical activity that was heavy(66.9\%). Generally, subjects were active or passive smokers $(83.4 \%)$ in both groups without a family history of DM (92.3\%).

The present study showed that the highest frequency of sago consumption was ( $1 \mathrm{x} /$ day,> $1 \mathrm{x} /$ day) $39.22 \%$ with the number of sago consumption of $173.73 \pm 88.27 / \mathrm{g} /$ day. A percentage $(71.16 \%)$ of the subjects had consumed sago for more than ten years. The obtained measurements of RCBG from subjects were categorized as RCBG $<140 \mathrm{~mm} /$ dL compared to those of RCBG $140-200 \mathrm{~mm} / \mathrm{dL}$ subjects consuming sago $<140$ grams/day $(40.88 \%)$ and $\geq 140$ grams/ day $(52.28 \%)$, as presented in Figure 1.

\section{Subjects Condition of RCBG 140-200 mm/dL}

The results showed that the mean RCBG subject was $102.28 \pm 27.76 \mathrm{~mm} / \mathrm{dL}$, which was still within the range of the normal category (91.2\%), while RCBG 140-200 mm/dL was $8.8 \%$. The factors for incidence of RCBG 140-200 mm/dL were the variables in this study; BMI, SBP, DBP, cholesterol, and WC commonly categorized as normal (Table 2). 
There was no significant difference in RCBG 140$200 \mathrm{~mm} / \mathrm{dL}$ subjects between groups consuming sago $<140 \mathrm{~g} /$ day and $\geq 140 \mathrm{~g} /$ day in all variables. Educational levels, family income/month and family history of DM for RCBG <140 $\mathrm{mm} / \mathrm{dL}$ subjects were significantly different among the groups (Table 3).

The clinical sign showed no significant difference for RCBG 140-200 mm/dL subjects between group consuming sago $<140 \mathrm{gr} /$ day and $\geq 140 \mathrm{gr} /$ day for variables such as BMI, SBP, DBP, cholesterol, and WC. DBP and cholesterol in RCBG $<140 \mathrm{~mm} / \mathrm{dL}$ subject significantly differed between the groups (Table 4).

Table 5 illustrated Pearson'sx2 with p-value among factors. This assumed that those correlation among factors were highly significant with a p-value less than $0.01(<1 \%)$ and significant if a p-value less than $0,05(<5 \%)$. There were highly significant correlation between SBP, DBP and cholesterol $(\mathrm{p}=0.000, \mathrm{x} 2=59.8$ and $\mathrm{p}=0.001, \mathrm{x} 2=24.2)$ and among $\mathrm{WC}$ with BMI $(\mathrm{p}=0.000, \mathrm{x} 2=75.6)$. There were also significant correlation between sago consumption, cholesterol, and WC ( $\mathrm{p}=0.026, \mathrm{x} 2-16.5$ and $\mathrm{p}=0.019, \mathrm{x} 2=17.5)$; and between RCBG and SBP $(\mathrm{p}=0.013 . \mathrm{x} 2=18.4)$.

\section{Discussion}

The present study suggested that the effect of sago consumption could be seen from the measurement of RCBG in the two groups. Some studies showed that gender, age, and level of education were significant factors associated with the incidence of RCBG 140-200 mm/dL [15,5], while occupation and family income levels were not significantly associated with the incidence of RCBG 140-200 mm/dL [29,15].

Education determines a person's knowledge of the food pattern [33]. However, in general, high income and good work will lead to a person consuming high-fat and high-carbohydrate food, as well as a lack of consumption of food fiber which can cause a risk of RCBG 140-200 mm/dL [25]. Some studies suggested that a family history of DM was significantly associated with the incidence of T2DM [18].

An association between WC and BMI was found in the present study. Other studies have also demonstrated that obesity was a risk factor for RCBG 140-200 mm/dL [34,14]. Obesity can be seen from BMI which is usually associated with blood glucose levels in patients with T2DM and can be reduced by low GI and high fiber food consumption [19] Sago is

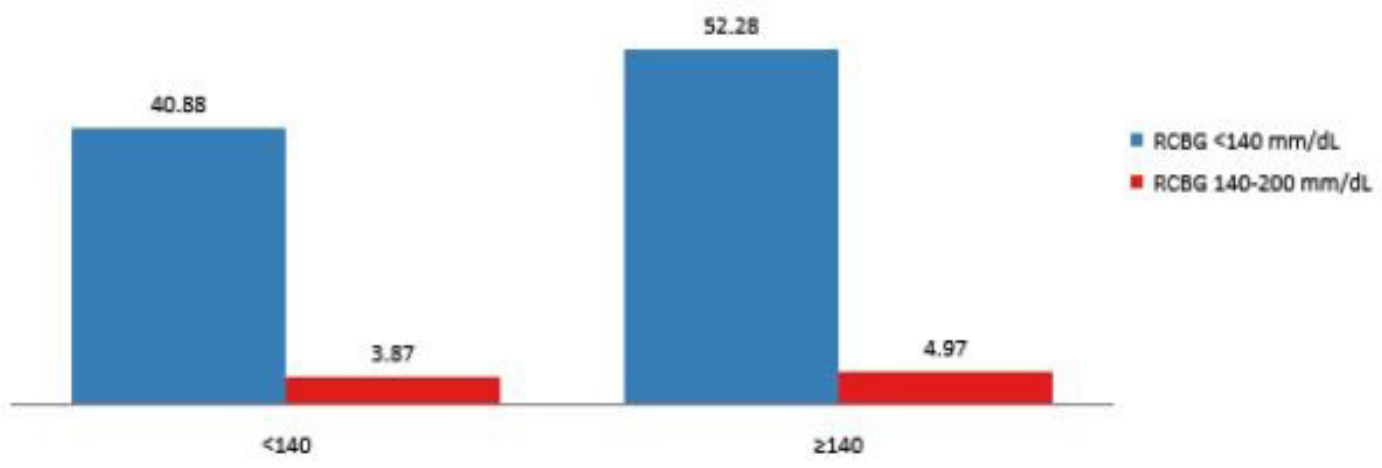

Sago consumption (g/day)

Figure 1. Random capillary blood glucose are based on the amount of sago consumption 


\begin{tabular}{|c|c|c|}
\hline \multirow[t]{2}{*}{ Characteristic } & \multicolumn{2}{|l|}{ Group consuming sago } \\
\hline & $\begin{array}{l}\text { Rarely }(\mathrm{n}=81) \\
\mathrm{n}(\%)\end{array}$ & $\begin{array}{l}\text { Often }(\mathrm{n}=100) \\
\mathrm{n}(\%)\end{array}$ \\
\hline \multicolumn{3}{|l|}{ Gender } \\
\hline Man & $26(32.1)$ & $36(36)$ \\
\hline Women & $55(64.9)$ & $64(64)$ \\
\hline \multicolumn{3}{|l|}{ Age } \\
\hline$<50$ year & $41(50.6)$ & $44(44)$ \\
\hline$\geq 50$ year & $40(49.4)$ & $56(56)$ \\
\hline \multicolumn{3}{|l|}{ Educational level } \\
\hline Low education & $66(81.5)$ & $91(91)$ \\
\hline High education & $15(18.5)$ & $9(9)$ \\
\hline \multicolumn{3}{|l|}{ Occupation } \\
\hline Not occupation & $23(28.4)$ & $29(29)$ \\
\hline Occupation & $58(71.6)$ & $71(71)$ \\
\hline \multicolumn{3}{|c|}{ Family Income/month } \\
\hline Low & $70(86.4)$ & $94(94)$ \\
\hline High & $11(13.6)$ & $6(6)$ \\
\hline \multicolumn{3}{|l|}{ Physical activity } \\
\hline High & $55(67.9)$ & $66(66)$ \\
\hline Moderat & $26(32.1)$ & $34(34)$ \\
\hline \multicolumn{3}{|l|}{ Smoking } \\
\hline Yes & $67(82.7)$ & $84(84)$ \\
\hline No & $14(17.3)$ & $16(16)$ \\
\hline \multicolumn{3}{|c|}{ Family History of DM } \\
\hline Yes & $9(11.1)$ & $5(5)$ \\
\hline No & $72(88.9)$ & $95(95)$ \\
\hline
\end{tabular}

Table 1. Characteristics of subjects from the group that consumes sago $<140 \mathrm{~g} /$ day and $\geq 140 \mathrm{~g} /$ day 


\begin{tabular}{|c|c|c|c|}
\hline \multirow[t]{2}{*}{ Variable } & \multicolumn{2}{|c|}{ Groups consuming sago } & \multirow[t]{2}{*}{ Mean \pm SD } \\
\hline & $\operatorname{Rarely}(\mathrm{n}=81)$ & Often $(n=100)$ & \\
\hline & $\mathrm{n}(\%)$ & $\mathrm{n}(\%)$ & \\
\hline RCBG & & & $102.28 \pm 27.76$ \\
\hline$<140 \mathrm{mg} / \mathrm{dL}$ & $74(91.4)$ & $91(91)$ & \\
\hline $140-200 \mathrm{mg} / \mathrm{dL}$ & $7(8.6)$ & $9(9)$ & \\
\hline BMI & & & $23.67 \pm 5.09$ \\
\hline $18.5-24.9 \mathrm{~kg} / \mathrm{m} 2$ & $49(60.5)$ & $69(69)$ & \\
\hline $25-27.0 \mathrm{~kg} / \mathrm{m} 2$ & $32(39.5)$ & $31(31)$ & \\
\hline SBP & & & $132.04 \pm 25.52$ \\
\hline $\operatorname{Normal}(<130 \mathrm{~mm} / \mathrm{Hg})$ & $42(51.9)$ & $52(52)$ & \\
\hline Hypertension $(\geq 130 \mathrm{~mm} / \mathrm{Hg})$ & $39(48.1)$ & $48(48)$ & \\
\hline DBP & & & $82.39 \pm 14.26$ \\
\hline Normal $(<80$ mm/Hg) & $42(51.9)$ & $64(64)$ & \\
\hline Hypertension ( $\geq 80 \mathrm{~mm} / \mathrm{Hg})$. & $39(48.1)$ & $36(36)$ & \\
\hline Choolesterol & & & $171.03 \pm 66.28$ \\
\hline Normal ( $\leq 200 \mathrm{mg} / \mathrm{dL})$ & $55(67.9)$ & $77(77)$ & \\
\hline High $(\geq 200 \mathrm{mg} \mathrm{dL})$. & $26(32.1)$ & $23(23)$ & \\
\hline WC & & & $85.21 \pm 12.08$ \\
\hline $\begin{array}{l}\text { Normal: Men }(<90 \mathrm{~cm}) \& \text { Women }(<80 \\
\mathrm{cm})\end{array}$ & $57(70.4)$ & $70(70)$ & \\
\hline $\begin{array}{l}\text { High risk: Men }(\geq 90 \mathrm{~cm}) \text { \& Women } \\
(\geq 80 \mathrm{~cm}) \text {. }\end{array}$ & $24(29.6)$ & $30(30)$ & \\
\hline
\end{tabular}

Table 2. Distribution of subjects' clinical sign

RCBG, random capillary blood glucose; BMI, body mass index, SBP, systolic blood pressure; DBP, diastolic blood pressure; Cholesterol; WC, waist circumferences 


\begin{tabular}{|c|c|c|c|c|c|c|}
\hline & $\begin{array}{l}\mathrm{RCBG}<140 \\
\mathrm{~mm} / \mathrm{dL}(\mathrm{n}=16)\end{array}$ & $\begin{array}{l}\text { RCBG } 140-200 \\
\mathrm{~mm} / \mathrm{dL}(\mathrm{n}=165)\end{array}$ & & & & \\
\hline & Rarely & Often & p-value & Rarely & Often & $\mathrm{p}$-value \\
\hline Gender & & & 0.257 & & & 0.659 \\
\hline Man & $2(28.6) 2)$ & $5(55.6)$ & & $24(32.4)$ & $31(34.1)$ & \\
\hline Women & $5(71.4)$ & $4(44.4)$ & & $50(67.6)$ & $60(65.9)$ & \\
\hline Age & & & 0.158 & & & 0.510 \\
\hline$<50$ year & $4(57.1)$ & $2(22.2)$ & & $37(50)$ & $42(46.2)$ & \\
\hline$\geq 50$ year & $3(42.9)$ & $7(77.8)$ & & $37(50)$ & $49(53.8)$ & \\
\hline Educational level & & & 0.727 & & & 0.000 \\
\hline Low & $6(85.7)$ & $8(88.9)$ & & $60(81.1)$ & $83(91.2)$ & \\
\hline High & $1(14.3)$ & 1(11.1) & & $14(18$. & $8(8.8)$ & \\
\hline Occupation & & & 0.705 & & & 0.957 \\
\hline No occupation & $2(28.6)$ & $3(33.3)$ & & $21(28.4)$ & $26(28.6)$ & \\
\hline Occupation & $5(71.4)$ & $6(66.7)$ & & $53(71.6)$ & $65(71.4)$ & \\
\hline $\begin{array}{l}\text { Family Income/ } \\
\text { month }\end{array}$ & & & - & & & 0.000 \\
\hline Low & $7(100)$ & $9(100)$ & & $63(85.1)$ & $84(93.4)$ & \\
\hline High & $0(0)$ & $0(0)$ & & 11(14.9) & $6(6.6)$ & \\
\hline Physical activity & & & 0.158 & & & 0.268 \\
\hline High & $4(57.1)$ & $7(77.8)$ & & $51(68.9)$ & $59(64.8)$ & \\
\hline Moderat & $3(42.9)$ & $2(22.2)$ & & $23(31.1)$ & $32(35.2)$ & \\
\hline Smoking & & & 0.727 & & & 0.715 \\
\hline Yes & $6(85.7)$ & $8(88.9)$ & & $61(82.4)$ & $76(83.5)$ & \\
\hline No & $1(14.3)$ & $1(11.1)$ & & $13(17.6)$ & $15(16.5)$ & \\
\hline Family History & & & - & & & 0.002 \\
\hline Yes & $7(100)$ & $9(100)$ & & $65(87.8)$ & $86(94.5)$ & \\
\hline No & $0(0)$ & $0(0)$ & & $9(12.2)$ & $5(5.5)$ & \\
\hline
\end{tabular}

Table 3. Subjects' demographic characteristics according to sago consumption All estimates were weighted and calculated taking the complex study design into account.

$\mathrm{P}$-value was obtained from a t-test independent, $\mathrm{P}$ value $<0.05$ 


\begin{tabular}{|c|c|c|c|c|c|c|}
\hline Characteristic & $\begin{array}{l}\mathrm{RCBG}<140 \mathrm{~mm} / \mathrm{dL} \\
(\mathrm{n}=16)\end{array}$ & $\begin{array}{l}\text { RCBG } 140-200 \mathrm{~mm} / \mathrm{dL} \\
(\mathrm{n}=165)\end{array}$ & & & & \\
\hline & Rarely & Often & $\mathrm{p}$-value & Rarely & Often & $\mathrm{p}$-value \\
\hline BMI (kg/m2) & & & 0.158 & & & 0.064 \\
\hline Normal & $4(57.1)$ & $7(77.8)$ & & $45(60.85 .1)$ & $62(68.1)$ & \\
\hline Overweight & $3(42.9)$ & $2(22.2)$ & & $29(39.2)$ & $29(31.9)$ & \\
\hline SBP $(\mathrm{mmHg})$ & & & 0.705 & & & 0.958 \\
\hline Normal & $5(71.4)$ & $6(66.7)$ & & $34(45.9)$ & $42(46.2)$ & \\
\hline Hypertension & $2(28.6)$ & $3(33.3)$ & & $40(54.1)$ & $49(53.8)$ & \\
\hline $\mathrm{DBP}(\mathrm{mmHg})$ & & & 0.705 & & & 0.033 \\
\hline Normal & $5(71.4)$ & $3(33.3)$ & & $34(45.9)$ & $33(36.3)$ & \\
\hline Hypertension & $2(28.6)$ & $6(66.7)$ & & $40(54.1)$ & $58(63.7)$ & \\
\hline Cholesterol $(\mathrm{mm} / \mathrm{Hg})$ & & & 0.258 & & & 0.025 \\
\hline Normal & $3(42.9)$ & $2(22.2)$ & & $23(31.1)$ & $21(23.1)$ & \\
\hline High & $4(57.1)$ & $7(77.8)$ & & $51(69.9)$ & $76(76.9)$ & \\
\hline $\mathrm{WC}(\mathrm{cm})$ & & & 0.257 & & & 0.747 \\
\hline Normal & $2(28.6)$ & $4(44.4)$ & & $22(29.7)$ & $26(28.6)$ & \\
\hline High risk & $5(71.4)$ & $5(55.6)$ & & $52(70.3)$ & $65(71 . .4)$ & \\
\hline
\end{tabular}

Table 4. Subjects' clinical signs according to sago consumption

All estimates were weighted and calculated taking the complex study design into account.

BMI, Body mass index; SBP, systolic blood pressure; DBP, diastolic blood pressure; WC, waist circumferences.

$\mathrm{P}$-value was obtained from a t-test independent, $\mathrm{P}$ value $<0.05$

\begin{tabular}{|l|l|l|l|l|l|l|}
\hline Sago consumption & & & & & & \\
\hline $\mathrm{x} 2$ & 12.6 & -8.6 & -13.4 & -16.5 & 17.5 & 9.1 \\
\hline $\mathrm{P}$ & 0.092 & 0.25 & 0.071 & 0.026 & 0.019 & 0.221 \\
\hline RCBG & & & & & & \\
\hline $\mathrm{x} 2$ & & 18.4 & -5.4 & 0.9 & 9.8 & -112 \\
\hline $\mathrm{P}$ & & 0.013 & 0.472 & 0.906 & 0.188 & 0.875 \\
\hline SBP & & & & & & \\
\hline $\mathrm{x} 2$ & & & 59.8 & 24.2 & 8.1 & -2.7 \\
\hline P & & & 0.000 & 0.001 & 0.279 & 0.715 \\
\hline DBP & & & & & & \\
\hline $\mathrm{x} 2$ & & & & 8.3 & 11.1 & 9.3 \\
\hline P & & & & 0.266 & 0.136 & 0.211 \\
\hline Cholesterol & & & & & & \\
\hline $\mathrm{x} 2$ & & & & & 1.5 & -11.8 \\
\hline P & & & & & 0.845 & 0.113 \\
\hline WC & & & & & & \\
\hline $\mathrm{x} 2$ & & & & & & 75.6 \\
\hline P & & & & & & 0.000 \\
\hline
\end{tabular}

Table 5 Correlation among significant factors among subjects consuming sago

All estimates were weighted and calculated taking the complex study design into account.

RCBG, random capillary blood glucose; BMI, Body mass index; SBP, systolic blood pressure; DBP, diastolic blood pressure;

WC, waist circumferences.

$\mathrm{P}$-value was obtained from a Pearson correlation test, $\mathrm{P}$-value $<0.05$ 
a low GI food. This mechanism occurs because the suspension of food (chyme) reaches the small intestine slowly, absorption of glucose in the small intestine becomes slow, and fluctuations in blood glucose levels are also relatively small [1].

Association between sago consumption, cholesterol and WC supported by a study by Amir et al., [2] showed that sago consumption patterns could affect the levels of LDL. Trisnawati et al.,[33] showed that cholesterol levels were significantly associated with the incidence of RCBG 140-200 mm/ dL. Some studies suggested that WC was significantly associated with the incidence of T2DM [26-27], causing an increase in FFA, damaging pancreatic $\beta$ cells that could produce insulin due to lipotoxicity [20]. This mechanism occurs because cholesterol plays a role in pancreatic beta cell dysfunction through an increase in serum cholesterol which increases pancreatic cholesterol and free fatty acids, especially in the case of obesity [13].

In the present study, it was observed that there were associations between RCBG and SBP. Several studies have shown that blood pressure was significantly associated with the incidence of RCBG 140-200 mm/dL which mechanism was related to high sodium intake causing changes in insulin sensitivity and insulin plasma concentration associated with nitric oxide pathways $[15,33,22]$.

The carbohydrate adequacy of the subjects in this study, besides rice, was fulfilled by sago which had high fiber and amylose content, resulting in more resistant starch which became prebiotics for the intestines and facilitated digestion [24]. The high amylose content in sago was due to the presence of $\alpha$ - $(1,4)$ - glycosidic bonds that were not branched with a more crystalline structure and stronger hydrogen bonds, making it difficult to be hydrolyzed by digestive enzymes and resulting in slow digestion. High levels of amylose also slow down the digestion of starch to cause low IG [3]. The high content of sago fiber also affected blood sugar [8]. The subjects in this study had normal energy and carbohydrate intakes $(1,848 \mathrm{kcal}$ and $284.5 \mathrm{~g}$, respectively), normal energy and carbohydrate adequacy levels(91.9\% and 93.6\%, respectively). However, there was a mild deficit in protein intake and level of adequacy (48.3 $\mathrm{g}$ and $84.9 \%$, respectively), with even excessive fat intake.

\section{Limitations and Strengths of the Study}

This study had several benefits. Specifically, it was one of the community nutrition studies to find out the effect of sago consumption among people consuming sago for a long time. Despite these benefits, our study had some limitations. It did not measure the fasting blood glucose or postprandial blood glucose and profile lipid of the subjects.

\section{Conclusion and Recommendation}

In conclusion, RCBG subjects were categorized as $<140 \mathrm{~mm} /$ rather than RCBG 140-200 mm/dL with normal BMI in both groups. There was a significant correlation between sago consumption with cholesterol and WC. The results of this study provided an alternative food to control NCDs signs through planning meal and dietary management with sago product.

\section{Acknowledgments}

This work was supported by the Ministry of Technology Research and Higher Education of the Republic of Indonesia in the grant of the National Strategy research scheme. The author thanks the ten enumerators who volunteered to collect the data. We would also express our thanks to the subjects who voluntarily participated in this study.

\section{References}

1) Adnan M, Tatik M, Joko TI (2013) Relationship of body mass index (BMI) with blood glucose levels of patients with diabetes mellitus (DM) type 2 outpatient at Tugurejo Hospital Semarang. J. NutrSemarang Muhammadiyah Univ 2:18-24.

2) Amir S, Burhaniddin B, Tahir A (2017) Effect of sago consumption pattern on LDL and HDL in women 35-55 years North Luwu. Int J Behav Health Res 2:22-30.

3) Arif, Abdullah B, Agus B (2013) Glycemic Index District of Foods and Its Affecting Factors. J. Litbang Per 32:91-99.

4) (2016) American Diabetes Association. Classification and diagnosis of diabetes. Diabetes Care 39:513-522.

5) Bark El-Sayed (2015) Nutritional assessment of type II diabetic patient. Pak J Nutr 14:308-315.

6) Bintoro HMH (2016) Sago for Indonesia's development. Paper at the Sago National Seminar and Workshop 9-10 November. Bogor.

7) Erwin P, dan Karmini N (2012) Indicators of income, family members, and level of education on consumption patterns of poor households in Gianyar District. E-Jurnal Ekonomi Pembangunan1:1-60. 
8) Fitri RI dan Yekti W (2012) Energy intake, carbohydrate, fiber, glycemic load, physical exercise, and blood glucose levels in patients with type 2 diabetes mellitus.Media Medika Indonesiana 46:121-131.

9) Hu FB (2011) Globalization of Diabetes: The Role of Diet, Lifestyle, and Genes. Diabetes Care 34:1249-1257.

10) Hu EA, Vasanti Malik, Qi Sun (2012) White rice consumption and risk of type 2 diabetes: Meta-analysis and systematic review. BMJ 344:e1454.

11) Hariyanto B (2014) The development of sago-based food product technology to support food availability. Agency for the Assessment and Application of Technology. Serpong.

12) Hariyanto B, Agus TP, Y Marsono, Sri Budi W, Agus W, et al. (2016) Study of sago rice consumption for normal volunteers. Agency for the Assessment and Application of Technology. Serpong.

13) Hingle DM, Betsy CW, Marian LN, Lesley FT, et al. (2017) Association between Dietary Energy Density and Incident Type 2 Diabetes in the Women's Health Initiative. J Acad Nutr Diet 117:778-785.

14) Hegazi R, Mohame EG, Nagy AH, Osama H. (2015) Epidemiology of risk factors for tpe 2 diabetes in Egypt. Ann Glob Health 81:814-820.

15) Idris H, Hamzah H, Feranita (2017) Analysis of diabetes mellitus determinants in Indonesia: A study from the Indonesian basic health research. Acta Med Indones49:291-298.

16) (2015) [IDF] International Diabetes Federation. IDF Diabetes Atlas Seventh Edition. Karakas Print. New York

17) Korrapati D, Shanmugam MJ, Sangamitra K, Laxmi RP, Vani A, ET AL. (2018) Development of Low Glycemic Index Foods and Their Glucose Response in Young Healthy NonDiabetic Subjects. Prev. Nutr. Food Sci 23:181-188.

18) Kral BG, Becker DM, Yanek LR, Vaidya D, et al. ( 2018) The relationship of family history and risk of type 2 diabetes differs by ancestry. Diabetes and Metab. Artikel in Press.

19) Laksir H, Mirian L, Sophie CR, Johan DV-VDB, (2017) Glycaemic response after intake of high energy, high protein, the diabetes-specific formula in older malnutrished or at risk of malnutrition type 2 diabetes patients. Clin Nutr 37:20842090.

20) (2013) Ministry of Health Republic of Indonesia. Basic health research. Jakarta (ID): Health Research and Development Agency.

21) Momuat L.I, Edi.S, Olha.R, Aneke.K, et al. (2015) Comparison of phenolic compounds and antioxidant activities between fresh and dried sago. Chem. Prog 8:20-27.

22) Pavlou, Dimitra I (2018) Hypertension in Patients with Type 2 Diabetes Mellitus: Targets and Management. Maturitas112:71-77.

23) Punthakee, Zubin, Ronald Goldenberg, and Pamela Katz (2018) Definition, Classification, and Diagnosis of Diabetes, RCBG 140-200 mm/dL and Metabolic Syndrome Diabetes Canada Clinical Practice Guidelines Expert Committee. Can J Diabetes 42: 10-15.

24) Purwani EY, Y Setiawaty, H Setianto, Widaningrum (2006) Characteristics and case studies of the preference of sago noodles by the community in South Sulawesi. AGRITECH 26:2433.

25) (2012) Putra FD dan Mahmudiono T. Relationship between the level of consumption of carbohydrates, fats, and dietary fiber with blood glucose levels in patients with type 2 diabetes mellitus. Media Gizi Indonesia 2:1528-1537.

26) Reed J, Sudaba M, Mary M, Stewart BH, et al. (2016) Dietary pattern and type 2 diabetes mellitus in a first nations community. Can J Diabetes 40: 304-310.

27) Rompay MIV, Nicola MM, Carmen CS, Jose MO, et al. (2012) Carbohydrate nutrition differs by diabetes status is associated with dyslipidemia in Boston Pusrto Rican adult without diabetes. J. Nutr143:182-188.

28) Sar S, Marks GC (2015) Estimated effects of white rice consumption and rice variety selection on the incidence of type 2 diabetes in Cambodia. Public Health Nutr 18:2592-2599.

29) Siddiqui FJ, Bilal IA, Sadia M, Debra JN, et al. (2015) Uncontrolled diabetes mellitus: Prevalence and risk factors among people with type 2 diabetes mellitus in an Urban District of Karachi, Pakistan. Diabetes Res Clin Pract 107:148-156. 
30) Su-Jung Cho, Un Ju Jung1, Hye-Jin Kim, Ri Ryu, Jae Young Ryoo, et al. (2015)Effects of the Combined Extracts of Grape Pomace and Omija Fruit on Hyperglycemia and Adiposity in Type 2 Diabetic Mice. Prev. Nutr. Food Sci 20:94-101.

31) Tabak AD, Christian H, Walfgang R, Eriz B, et al. (2012) Pre diabetes: a high-risk state for diabetes development. The Lancet 379: 2279-2286.

32) Tarigan EP, Lidya IM, Edi S (2015) Characterization and antioxidant activity of Baruk sago flour. J. MIPA UNSRAT online 2015;4:125-130.

33) Trisnawati, Shara Kurnia, and Soedijono Setyorogo (2012) Risk Factors for Diabetes Mellitus Type II Occurrence in Cengkareng District Health Center, West Jakarta. Health Sci J 5:6-11.

34) Watson C (2017) Pre diabetes: Screening, diagnosis, and intervention. J Nurse Pract 13:216-221.

35) Wahjuningsih SB, Y Marsono, Danar P, Bambang $\mathrm{H}$ (2016) Resistant starch content and glycaemic index of sago (Metroxylon spp) starch and red bean (Phaseolus vulgaris) based anslogue rice. Pak J Nutr 15:667-672.

36) (2016) World Health Organization(WHO). Global Report on Diabetes. WHO Pres, Switzerland

37) (2016) World Health Organization (WHO). World Health Statistics 2016: Monitoring health for the SDGs. World Health Organization.
Submit your manuscript to a JScholar journal and benefit from:

9 Convenient online submission

I Rigorous peer review

- Immediate publication on acceptance

ब Open access: articles freely available online

ब High visibility within the field

- Better discount for your subsequent articles

Submit your manuscript at http://www.jscholaronline.org/submit-manuscript.php 